\title{
Psychiatry past and present in the Russian territory of Primor'e
}

\author{
S.A. Alekseyev
}

Primor'e is a former Soviet colonial area in the Far East. It is now part of free Russia's national parkland, rich in flora and fauna. In the present chaotic period of transition to a market economy, business leaders from Japan, China and Korea have rushed in to develop its potential.

The main city in Primor'e is Vladivostok. The psychiatric service, however, originated in the town of Ussurisk, where the first psychiatric hospital was built by public subscription in 1904, and staffed by highly educated people such as I.D. Shcherbak who graduated from the University of Yurevsky (previously Derptsky), where he was taught by Kraepelin himself. He visited many progressive mental hospitals, both at home and abroad. During World War I, he was evacuated to the Far East, and worked in the mental hospital at Ussurisk.

The doctors of the pre-Soviet period had a European approach to psychiatry, but this ended with the arrival of those educated under the communist regime. Professor Lastovetsky who worked in Ussurisk from 1922, wrote that:

"The struggle for the health of the working people, including their mental health, has entered a new phase, bringing us closer to a bright future for mankind and to the building of a happy communist society.

"The chief objective is to incorporate the scientific principles of Soviet psychiatry into everyday practice in the Ussurilsk Hospital."

It is a bitter fact that these principles still operate today.

Psychiatry is a branch of medicine in which medical and human problems are closely interwoven. Psychiatric disorders do not present objective signs in the same way as physical disorders such as diabetes. There is no single conclusive test for schizophrenia. Consequently the role of psychiatrists is a powerful one: they determine the fate of the patient. Diagnostic methods are therefore of vital importance. In every Soviet psychiatric hospital, the chief psychiatrist has the final say in all matters. He heads all commissions of any importance, and settles any disputes about diagnosis. He goes through the motions of asking his colleagues' advice, but they all know that they are completely dependent upon him. He is always right by virtue of his position.

During the Soviet period, the Moscow school of psychiatry (led by A. Snezhnevsky) held sway in the Primor'e region; indeed, it still does. The diagnostic methods and the approach of the Moscow school brought with them formulations such as 'invisible symptoms of schizophrenia', and 'inertly-fluid schizophrenia'.

This situation lies at the root of Soviet psychiatric abuse. The state monopoly on psychiatry, its bureaucratic administration, the absence of mechanisms for free discussion, the suppression of dissenting views, the fear that initiative would be punished, and the state of psychiatry as a science have all contributed to the present state of affairs. To add to the list of our problems we may include the following: the irregular and disorganised provision of medicines and equipment to psychiatric hospitals and clinics; and an ineffective bureaucratic administration, which serves the concealed aims of members of the ruling group.

\section{Primor'e: the psychiatry of yesterday}

In 1987, a sick old man whom we will call Petrov was living in the town of $X$ in Primor'e. Petrov distinguished himself from his Soviet neighbours in that he made complaints to different authorities about the chairman of the town council, whom we will call Comrade A. Having previously worked under Comrade A, Petrov knew all about his machinations. Comrade $A$ was weary of Petrov, and found a way of dealing with him.

A Dr B was invited to take part in a commission which was looking into the Petrov affair. He was even sent to Petrov's flat to 'examine' him. Dr B arranged to send Petrov to the Regional Psychiatric Hospital no. 1 at Ussurilisk. Dr B justified this action on the grounds that Petrov was 'making complaints' and 'fighting for justice'. He 
diagnosed a paranoid syndrome with 'querulous tendencies'.

Petrov was seized at his summer cottage in the country, without explanation. The ambulance arrived; a policeman climbed out and put the old man in.

Petrov arrived at the psychiatric hospital in a state of shock, and asked to be discharged at once. Fortunately for him, a competent commission of enquiry, led by the assistant chief psychiatrist, sorted out the problem quickly, and he was discharged.

Following this, he made a complaint about the activities of Comrade $A$ and Dr B, as a result of which a commission of enquiry visited $X$. The commission consisted of representatives of the regional Public Prosecutor's office and of the regional Executive Committee, as well as the present writer. The commission brought to light numerous irregularities in the activities of both Comrade A and Dr B.

The commission took its findings to the chairman of the regional Executive Committee, Comrade $\mathrm{C}$, who is now a Governor. After listening to the report, Comrade $\mathrm{C}$ gave this astonishing reply: "We won't hurt our leader's feelings. Petrov had no right to make those allegations!"

It is not known where Petrov is now, but the other players in this psychiatric comedy are still in their places, with some adjustments. During his time as Governor, Comrade $\mathrm{C}$ was dismissed for bribery. He now heads the regional fund for the privatisation of property. He gives instructions on privatisation and puts reforms into practice.

\section{Primor'e: the psychiatry of today}

The following example illustrates the standard of recent psychiatric administration. The findings were made in 1992.

In the territory of Primor'e, there are four large psychiatric hospitals and two neuropathological clinics/hospitals. These institutions are short of space and overcrowded. Admission and discharge rates are high.

There is, however, one exception, which we will call hospital $H$. This establishment occupies a special place in the regional psychiatric service. For the last 16 years, Dr D has been the chief psychiatrist there. She hires and fires, decides on building work and closures, introduces new methods and gives medical advice, transfers patients between sections and punishes and reprieves her subordinates.

Hospital $\mathrm{H}$ is closed, not only to ordinary mortals, but also to psychiatrists. It is difficult, therefore, to find out what goes on there. However, I was able to visit this hospital as a member of a commission. Its report, which was pub- lished in the Primor'e Psychiatric Bulletin No. 9. November 1992, was as follows:

"(Hospital H) is the only psychiatric institution to have been built according to a complete design. It occupies large grounds (389 012 sq.m.) and it has a large farm, with fields, a garden, a greenhouse, a piggery, a herd of cows, etc. It is a town in itself, situated in the green belt $20 \mathrm{~km}$ from Ussurisk. According to official figures for 1991, the hospital has 620 beds. It is the largest psychiatric hospital in the region, and comprises two spacious modern buildings. Living conditions are excellent.

"The number of patients in the hospital has decreased rapidly, from 1045 in 1988 to 145 in 1991. The most recent building, completed in 1990, has never been used for psychiatric patients and is two thirds empty. It appears that there is a deliberate policy of avoiding admissions. Between January and November 1992, 101 patients were admitted, compared with 665 admissions to a 100-bed unit at No. 1 Hospital and 250 patients to a 30-bed psychiatric unit in Lesozavodsk town hospital."

The commission concluded that there was no organised practice of psychiatry, as generally understood. Patients were refused admission in spite of the fact that large parts of the hospital were empty. The administration of this hospital appeared capricious and wasteful of time and money, while other psychiatric hospitals in the region laboured under an intolerable load. The situation demanded the immediate replacement of the chief psychiatrist.

A few days after presenting the report, the members of the commission discovered that they had achieved the expected result, no result at all. Dr D remains in control of the hospital, failing to use it for its intended purpose. The chief psychiatrist of Primor'e adopted an ambiguous position: while admitting the existence of numerous abuses at Hospital $\mathrm{H}$, he took no steps to change the situation, or to use the generous resources of the hospital for the benefit of the underfunded and overloaded psychiatric service of the whole region. An experienced local psychiatrist expressed the opinion that the psychiatrist at Hospital $\mathrm{H}$ had protectors in the regional health administration who condoned her caprices.

Delegations come to our region, and sometimes there are visits by foreign psychiatrists. Ordinary psychiatrists do not have the privilege of meeting such unusual guests; generally it is our leaders who meet them. Recently some foreign psychiatrists were taken to Hospital $\mathrm{H}$ and of course they were impressed. No doubt it is regarded as a model hospital, and the pride of our authorities. 
Today we find ourselves at a crossroads. Opinions differ as to how we may best organise our work under changing conditions. My opinion is that since we have no mechanism for the free exchange of opinions, official views, those of the authorities, will prevail. The Russian government has excluded psychiatry from the move towards medical insurance financing. All other branches of medicine must set to work on their standards and make agreements with insurance companies. Psychiatry is left with state bureaucratic funding, and with no alternative method of financial support.

Many psychiatrists have joined our local Independent Association of Doctors of Primor'e, which was started in 1991, and which publishes a Psychiatric Bulletin*. But we have encountered opposition to this from official psychiatry in the form of the Association of Psychiatrists, Psychotherapists, Narcologists and Neuropathologists.

*Primor'e Psychiatric Bulletin

First published December 1990

Chief editor: Dr S.A. Alekseyev

Editor: Dr G.G. Gomeniuk

Regional Psychiatric Hospital No. 1, Sukhanova 16 692519 Ussurilisk, Primorskil krai, Russia
We continue with our attempt to form an Independent Psychiatric Association, but while our society is suffering from disruption and fragmentation, many people, including doctors, feel that under the present conditions, it is a case of 'every man for himself.

The 'Law on Psychiatric Assistance and on Guarantees of Human Rights during its Rendering' came into force on 1 January 1993. If this law is observed in the everyday practice of psychiatry, it will guard against abuse. It brings Russian psychiatric legislation in line with world norms.

We hope that these troubled times will pass, and that there will be an end to Russia's economic chaos; that the standards of the civilised world will be confirmed in Russian psychiatry, and that the mentality of our psychiatrists will change.

We hope also that we may look to European psychiatrists, who have played a major historical role in Russian psychiatry, to help us today.

S.A. Alekseyev, Chief of Medical Service, Primorsky Regional Mental Hospital No. 1, Russia 692503

\section{( Liaison Psychiatry Defining Needs and Planning Services \\ Edited by Sidney Benjamin, Allan House and Peter Jenkins}

Liaison Psychiatry: Defining Needs and Planning Services is the first British book to examine the need for liaison psychiatry services, their scope, planning, organisation and management.

The first section describes the scope of liaison services, the assessment of needs that they should meet and the demands that are placed upon them, especially by the medically ill and chronic somatisers. General and specialised services for different groups of patients, including children and the elderly, are then outlined. The final section discusses the organisation of undergraduate teaching and postgraduate training, and the contribution of research to liaison services.

The book will be of interest to liaison and other psychiatrists; managers of mental illness units and general hospitals; purchasers in health authorities and general practice; and psychiatrists in training, who will be the future service providers.

- $10.00 \bullet 119 p p . \bullet 1994 \bullet$ ISBN 0902241699

Available from the Publications Department, Royal College of Psychiatrists, 17 Belgrave Square, London SW1X 8PG (Tel. 0171-235 2351) 